\title{
MANAGEMENT MODELS OF A SCIENCE AND TECHNOLOGY PARKS: FOREIGN EXPERIENCES AND RECOMMENDATIONS FOR POLAND
}

\begin{abstract}
Summary
The paper presents four management models of a scientific-technological park built on the basis of the in-depth analysis results of fifteen selected parks in the world. The basic functions of the park were discussed as well as the pros and cons of each model showing the possibilities for their further development. The reference was made to the Polish conditions, indicating that two corporate and network models are the most suitable for Poland. The corporate model based on the active cooperation of technical universities and public and private entities is, according to the authors, the most suitable for use in the case of science and technology parks located near a technical university. The corporate model is an alternative to the network model which allows to create science and technology parks with a dispersed spatial structure.
\end{abstract}

Keywords: science and technology park, models of management, creative space, network approach, research and development

\section{Introduction}

The subject of this research paper is science and technology parks as the structures that have been participating in the process of the translation of research achievements into economic practice over fifty years. A lot of experience has been gained during these years, searching for more and more effective models leading to the achievement of the primary goal set for the parks since the very beginning of their existence - to boost the results of research conducted by universities in the economic and social dimension, focused on creating innovation that supports economic development. The first parks, established in the USA and Europe, were strongly connected to universities and as they became more popular and developed, they evolved into more diversified forms. This has led science and technology parks to emerge as separate organizations linking various entities within a certain region, beyond the border of a region or even a country. The processes of globalization, internationalisation of research, the invention of the Internet and the development of the broadly defined network economy have played

\footnotetext{
1 Assoc. prof. dr hab. Stanisław Łobejko - Collegium of Business Administration, Warsaw School of Economics, e-mail: slobej@sgh.waw.pl. Prof. dr hab. Alicja Sosnowska - Szkoła Wyższa im. Pawła Włodkowicaw Płocku, e-mail: alicja.sosnowska22@gmail.com
} 
a particular role here. Thus the $21^{\text {st }}$ century methods and models of management of science and technology parks, contrary to the $20^{\text {th }}$ century, have evolved. Along with science or science and technological parks, industrial parks, industrial and technology parks or even clusters have appeared. Besides the goal to transfer technology, additional objectives have appeared aimed at region development, employment growth, the stimulation of international cooperation, etc.

Hence, it seems to be appropriate to broaden the definition of the science and technology park in the context of cooperation with a single university or more than one university and to distinguish it from other structures defined in literature, such as technology parks, clusters or business incubators, etc. It is especially significant in terms of defining the role of science and technology parks for today's entrepreneurial universities and to the growth of a region and the economy in general.

The aim of this paper is to present the way to reach a new model of a science and technology park as a network organization and to indicate the options to choose within the park management structures and its regional and international relations.

Based on the literature and interviews conducted among selected national and foreign parks, the authors of this paper state a thesis that today's science and technology parks strive for the integrated model operating in the network economy, organizationally separated from the university that combines the research activity with the activity of both a production and a service company and realize innovations that bring measurable economic and social benefits ${ }^{2}$.

At the same time, we would like to draw attention to the fact that parks operating in various countries are diversified, even though the goals they pursue are quite similar. The cause of this diversification is the need to adjust to the local environment. It gives the opportunity to choose an appropriate and individual park management model. However, it should comply with the legal framework and the general system of management rules [Setting up..., 2014, pp. 63-67].

All the aspects mentioned above require to specify the definition of a park and determine some institutional and financial standards it operates in. Since the practice of creating parks and its functioning indicates that as organizations of this kind have spread, problems have appeared in distinguishing a science and technology park from other organizations that mediate in technology transfer between science and practice, such as industrial parks (which gather enterprises that implement innovations in the industry) or a cluster.

2 The paper presents conclusions based on the international research of science and technology parks, carried out by the authors, as part of the initiative called: Przestrzen Kreatywna - Miasteczea Kreatymnego oraz, Potudniowego Obszaru Aglomeracï Warszanskiej, cofinanced from the European Regonal Development Fund. The whole project was conducted in the period of October-November 2014 for the Pro-Development company. The research included 15 parks and they are as follows: Adlershof Park (Germany), Zentrum für Luft und Raumfahrt Schönefelder Kreuz (Germany), Barcelona Science Park - Parc Cientific de Barcelona (Spain), Mediterranean Technology Park (Spain), Advanced Technologies Park/Ben Gurion University (Israel), Delaware Technology Park (USA), Virginia BioTechnology Research Park (USA), Manchester Science Park (England), Technopolis Oulu (Finland), Australian Technology Park (Australia), Hong Kong Science and Technology Parks Corporation (Hog Kong), Uppsala Science Park (Sweden), Sophia Antipolis (France), Birmingham STP (England), Cambridge Science Park (England). 


\section{The concept of a contemporary science and technology park}

A science and technology park is an important part/element of the innovation system of the country located in the area between the science and business and mediates the transfer of research results into business practice.

The awarding of science and technology park significant role in the national innovation systems also involves the assumption of an active participation of the state in the process of organizing and financing development of the park.

For the purpose of this study, it is assumed that the name of a science and technology park can take an organization that involves scientific and research organizations interested in the transfer and commercialization of technology infrastructure as an important component of $\mathrm{R} \& \mathrm{D}$ of innovative companies involved in the commercialization of innovation projects.

It is assumed that a science and technology park has close ties with the university and other research institutions. It cannot, therefore, be called a science and technology park of regional clusters of companies cooperating in the implementation of specific strictly business objectives. According to the classic definition of M. Porter it is a cluster. There is also a technology transfer center park, business incubator or another organization that serves the basic functions assigned to parks.

Not being bound to theory, it is assumed that a science and technology park is a structure (organization) which combines scientific and business activities thanks to the interaction of $\mathrm{R} \& \mathrm{D}$ and innovative companies using a common physical infrastructure and intellectual capital operating within the park organization of $\mathrm{R} \& \mathrm{D}$ and business. From experience we learn that operating parks that are usually involved in the business park combine territorial proximity, often sharing a particular area and volume and the joint management unit. The detailed arrangements for their ownership, financing, and powers of the liquidator and the participation of the park in the benefits derived from the commercialization of the projects and activities of enterprises are different and depend on the nature and structure of the park and the adopted management model.

The nature of science and technology determines the ratio between a part of the scientific and business ownership and industry (domain-), the specificity of the research activities and production and services. World experiences differ in this range widely. However, you can find some common features. As indicated by M. Weresa the concept of the park contains elements of research and business [Weresa, 2014, pp. 129-135]. The research part of maintaining a constant relationship with the university allows access to infrastructure and academic staff with high qualifications, which provides a high level of research undertaken, partly financed with public funds and efficiently transferring research results to continue their implementation by a business honor. These business area laboratories and companies implement innovations and benefit periodically from the surface and park infrastructure on the terms of a favorable lease and periodic tax preferences.

In the business you may also find place park tenants operating units offering services in network infrastructure, business administration and accounting, and design and training services [Strategiczne obszary..., 2011, pp. 15-16]. Both parties benefit from the 
combination of scientific and business parts in the immediate vicinity. Scientists provide direct cooperation with business and the ability to track further production and trade effects of the submitted projects. The benefits for business are particular access to information and research results, the possibility of permanent contacts with scientists, obtaining location for companies in the space of the prepared infrastructure, access to training offer and the possibility of cooperation with business partners also present in the park.

Additional benefits of co-location in a science and technology park could create a friendly environment - there are environmental, educational and cultural, sports centers found in many parks created abroad. All of this together adds up to define the creative space, which means a cluster of organizations and people making creative element in science, education, business, health and culture. They form what R. Florida calls the creative class environment. A creative class consists of people whose economic function is to create new ideas and concepts i.e. new creative content.

In this way, a lot of science and technology parks have created a kind of creative community conducive to the development of innovation and increasing the competitiveness of the business part of the park. The objective of creating such a community can be a leading idea for instantiation model park management. In an attempt to analyze existing and develop new models for the management of scientific and technological park, it is assumed that:

- Firstly - all models include acting through the park both scientific functions described above as well as business;

- Secondly - the park is an entity defined territorially and administratively;

- Thirdly - participants of (members of) the park are scientific institutions (universities, institutes), entrepreneurs, business start-ups, academic, public (aid organizations - PARP ARP) and social organizations (associations, engineering organizations);

- Fourthly - choice of models using foreign experience, but with a possibility to adjust them to the Polish conditions;

- Fifthly - it assumes creation of a central unit acting as the park with organizational and managerial functions in relation to other participants in the park.

The proposals are the framework which can provide a basis for discussion and then after the election must be made more precise and adapted to local conditions.

\section{Models of management systems of a science and technology park}

On the basis of available knowledge, as it seems, the following models of a science and technology park with their corresponding management systems can be extracted:

Model I - a university science park - the park is an integral part of the university,

Model II - an independent organization - a Limited Liability Company,

Model III - a corporate park - a stock company,

Model IV - a network park. 
These models have been separated according to the criteria of ownership and management system. In the following parts characteristics of these models along with an attempt of preliminary assessment of the advantages and disadvantages of adopting a given solution are presented.

\section{Model I - University science park}

The basic functions of the park is creating a campus on a university, or in the immediate vicinity some special space and infrastructure to enable research carried on by university staff and students and - implementation works along with the ability to create business start-ups and spin-offs. The premise of the park is creating an innovative environment for innovators and enabling them to transform themselves into entrepreneurs. The University may provide certain services to the participants of the park and researchers working in the park who may provide educational services for example conducting graduate work of students, running laboratory classes for students, etc.

At the same time, the task is to create space conditions (area for research) and staffing to allow intensifying research that has its origin among the university staff. A park is administratively a separated part of the university having its own unit manager who, however, as subject to the rector's authorities fulfills the obligations arising from the statutes of the school and benefits from public funds (grants awarded to universities for research) and university infrastructure. The university participates in the means developed by companies belonging to the park. To reconcile the independence of the companies set up in the park and conducting commercial activities within the administrative structures of universities is a very important issue. This can cause a lot of conflicts. Thus, participants in the park after reaching commercial success are interested in reaching their independence (autonomy).

As shown in Chart 1, a university park is a separate administrative unit incorporated into the administrative structure of the school, allowing working closely with researchers conducting scientific work at faculties and laboratories as well as the creation of separate research laboratories and service units under park management. The level of independence of the parks management both in conducting research (selection and ways of financing research topics) and in commercial activities (acceptance of orders, sales projects) is essential.

Advantages of the university model:

- $\quad$ close contact with the university which enables the smooth takeover of subjects capable of being commercialized in the structures of the park,

- free flow of information and academic staff between the university and the park,

- $\quad$ the use of administrative units of the university to support the park,

- the use of common infrastructure,

- connecting the park with the university brand [Analiza..., 2014, p. 49]. 


\section{CHART 1.}

Model of the science park structure operating within the university

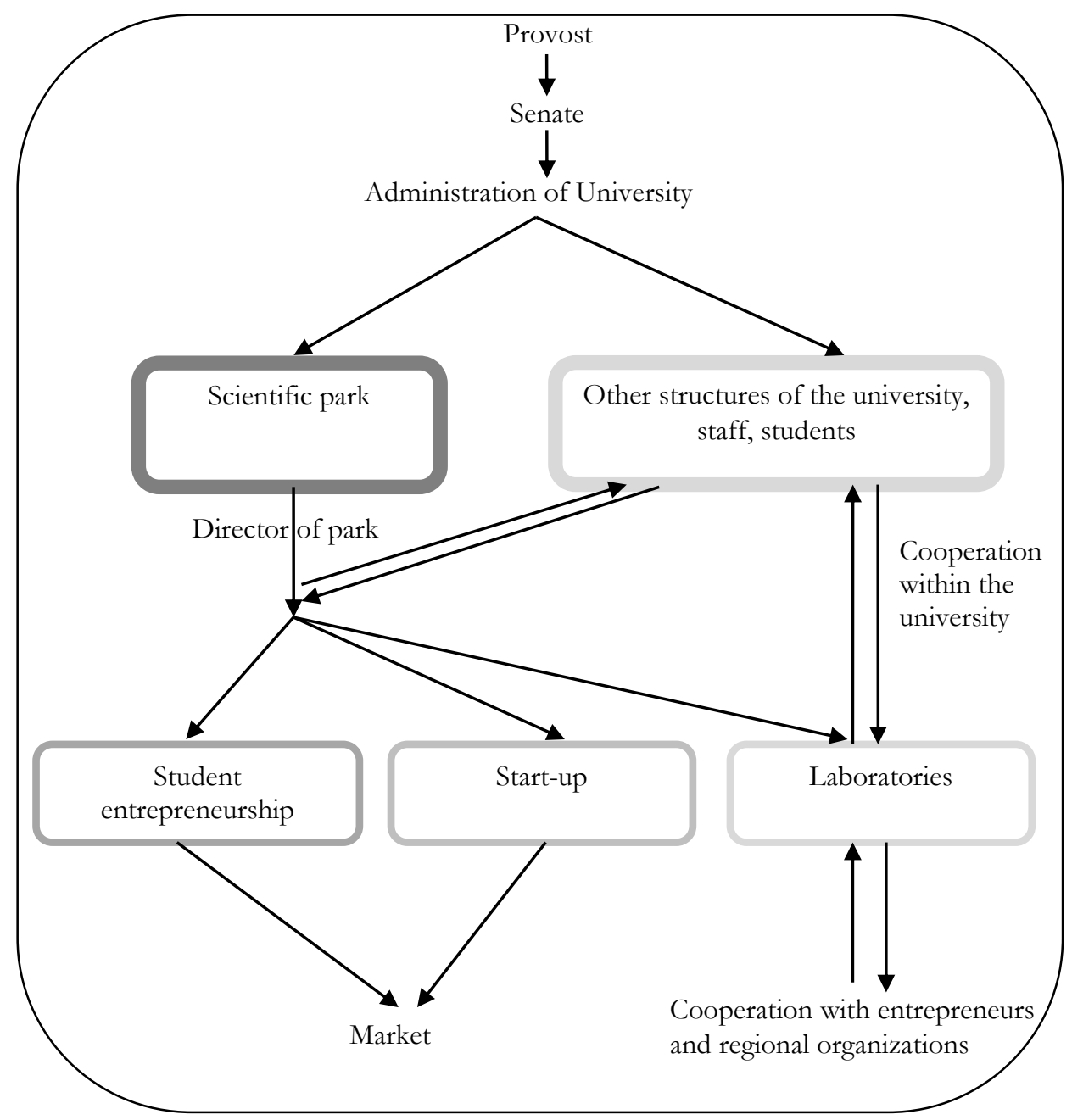

Source: author's own work [Analiza..., 2014, p. 49].

Disadvantages arising from the operation of the park in the structures of the university:

- $\quad$ limiting independence in decision making,

- the need to introduce at the university often bureaucratic procedures resulting in prolongation of decision making,

- the university is to blame for park failures or sometimes vice versa, 
- difficulty in separating the financial responsibility of the park and the university [Analiza..., 2014, p. 49]

These disadvantages cause that the university model, although proven in some American parks, receive criticism. Park participants negatively evaluate in this model a lack of independence and bureaucracy resulting from close ties with the university. However, in many cases, an important role of science and the significance of the university prevail in decisions about choosing this particular model. Moreover, the career of the leader park is also relevant. The scholar will be inclined to choose a university while the manager-entrepreneur is willing to choose the structure with greater independence. The analysis of some specific examples indicate that there is a wide variety of organizational solutions adopted for the university parks.

\section{Model II - Independent organization separated from the university on a company status}

Just like the previous one, this park model fulfills the scientific and research functions linked to business but is a distinct organization separated from the university, possessing its own headquarters and infrastructure, which is responsible for the results of operations of the entities belonging to it on its own.

The shareholders of the park on a company status are: the university or several universities, research institutes, innovative companies and organizations, regional development agencies, funding agencies as for example PARP, new venture capital funds as well as local government units (municipalities, counties). It is, therefore, a structure connecting both public and private companies. Together, as determined by the statute, they participate in financing investments, have joint responsibility for the activities of the company (according to the contributed shares) and share the benefits.

The Company is managed together by the president and management board and cooperates with the supervisory board elected by the shareholders of the park. According to the assumptions, the tasks of the park should be performed by both scientific research teams and innovative companies reported to the park by shareholders or approved by the park on the principles of tenancy. Different solutions about the functioning of the park and the rights of shareholders to benefits may be accepted. The base is always the company agreement and the statutes of the company.

Within this structure, especially in the first period, founding requires capital expenditure on the premises and its equipment, the creation of partners who will tie their future to the park and most of all research teams and entrepreneurs who want to participate in the development of the park. The fact that the park is a distinct science and business space also gives you the ability to create the so-called zone around the park to provide park tenants mutual not only scientific, but also social contacts, to exchange ideas and facilitate collaboration. There is also the possibility of building sports infrastructure, clubs, cafes, etc.

The model of the park, as an independent unit in the process of creating a park is shown in Chart 2. The figure presents the process of building the park, as the company's shareholders coming out of university (there may be several), research institutes or private funders interested in the commercialization of research results and 
business stakeholders, who are interested in locating their businesses in the infrastructure of the park. Shareholders are the founding group, which initiates the construction of the seat and park infrastructure then follows selecting a park management board and a scientific council, which together create the park infrastructure and invite future tenants. The next step is park organizing and its management.

CHART 2.

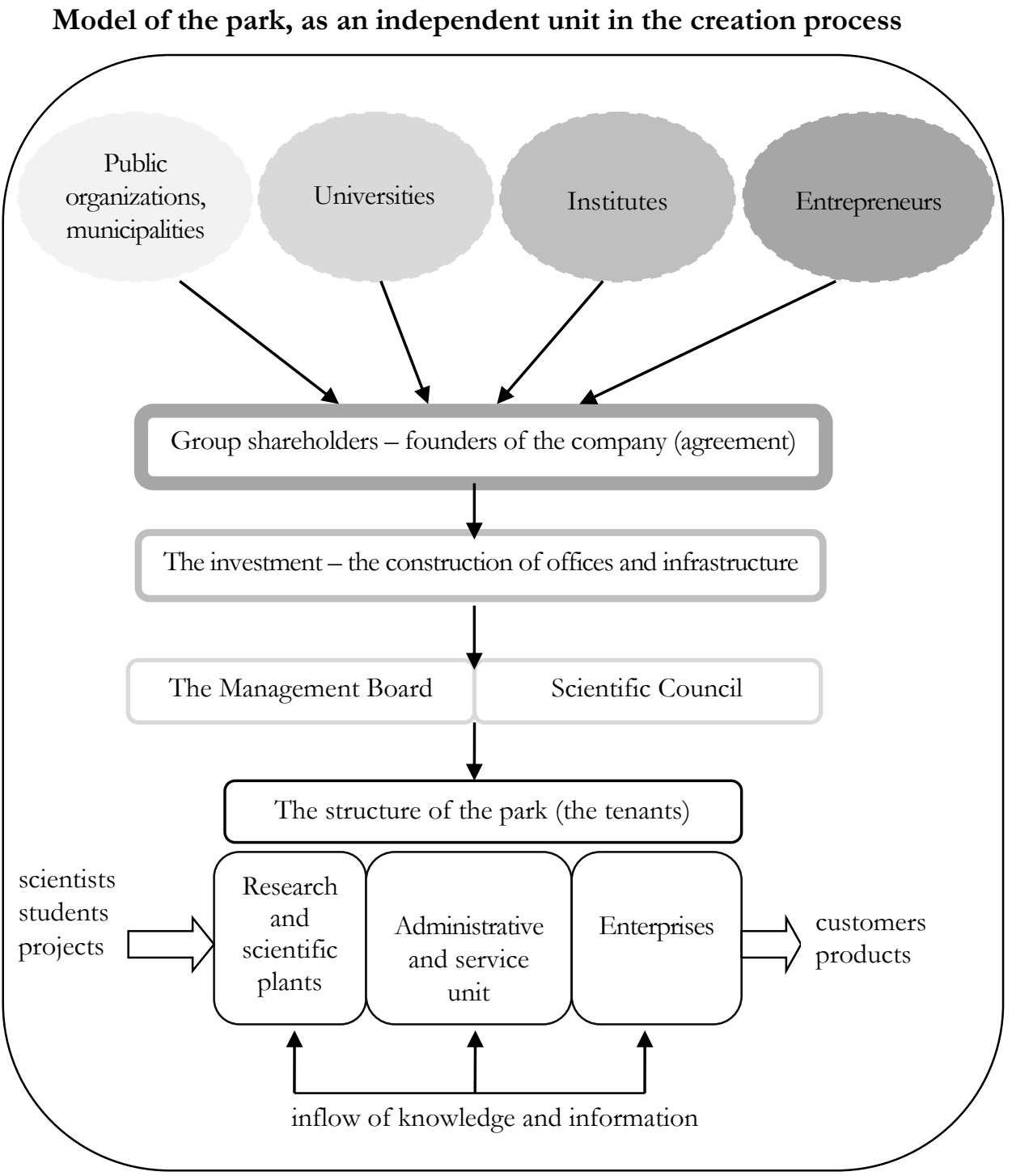

Source: author's own work [Analiza..., 2014, p. 51]. 
Advantages of choosing such a solution are as follows:

- a park is an organization separated from universities and other participating organizations on the basis of shareholders and such a system goes beyond the university structure;

- a separate Board of Directors and Scientific Council bears full responsibility before shareholders for the operations of the park;

- the Board has the opportunity to choose tenants of the park and the employment of workers according to the needs;

- $\quad$ apart from scientific activity and production it is possible to provide services and conduct information activities (e.g. Training);

- $\quad$ strong pressure to achieve positive financial results;

- structure of the park allows free access for many of the participants of the park [Analiza..., 2014, p. 52].

The disadvantages of this solution are:

- requires a significant initial capital investment;

- $\quad$ the risk that university employees may not want to move their activities to the park;

- a significant number of shareholders may hamper distribution of financial results;

- a long transition period from the start of investment to achieving economic benefits;

- uncertainty as to the fulfillment of obligations of shareholders agreed in the first period [Analiza..., 2014, p. 52].

\section{Model III - Corporate park}

The park is an independent organization established by a group of public and private founders acceding to the company as shareholders commencing business activities focused on the potential possibility of a return of capital in the long term. Leading shareholders make an initial capital as a result of the public sale of shares. Initial capital may constitute grounds for the park investment, financial resources, also from venture capital funds as well as intangibles like patents, licenses, new technologies implementation projects.

The park after a period of investment creates a space where companies conducting research or implementing the commercialization projects as well as start-up companies providing production or services can be located. All companies belonging to the park are its shareholders and participate in the business results. It is possible to exit the park and regain independence on the principle of spin-outs. In this model, it is assumed that after the first period of operation, when the park relies heavily on external capital (loans, grants) it can start working on the corporate principles.

It is significant that the corporate model is based on the use of cooperation of the aforesaid shareholders and stakeholders. These include local authorities and the local community interested in the park location (jobs, infrastructure), entrepreneurs potential customers of the park, other than shareholders potentially collaborating research institutions built around the park in the creative space. 
Model of the corporate park

CHART 3.

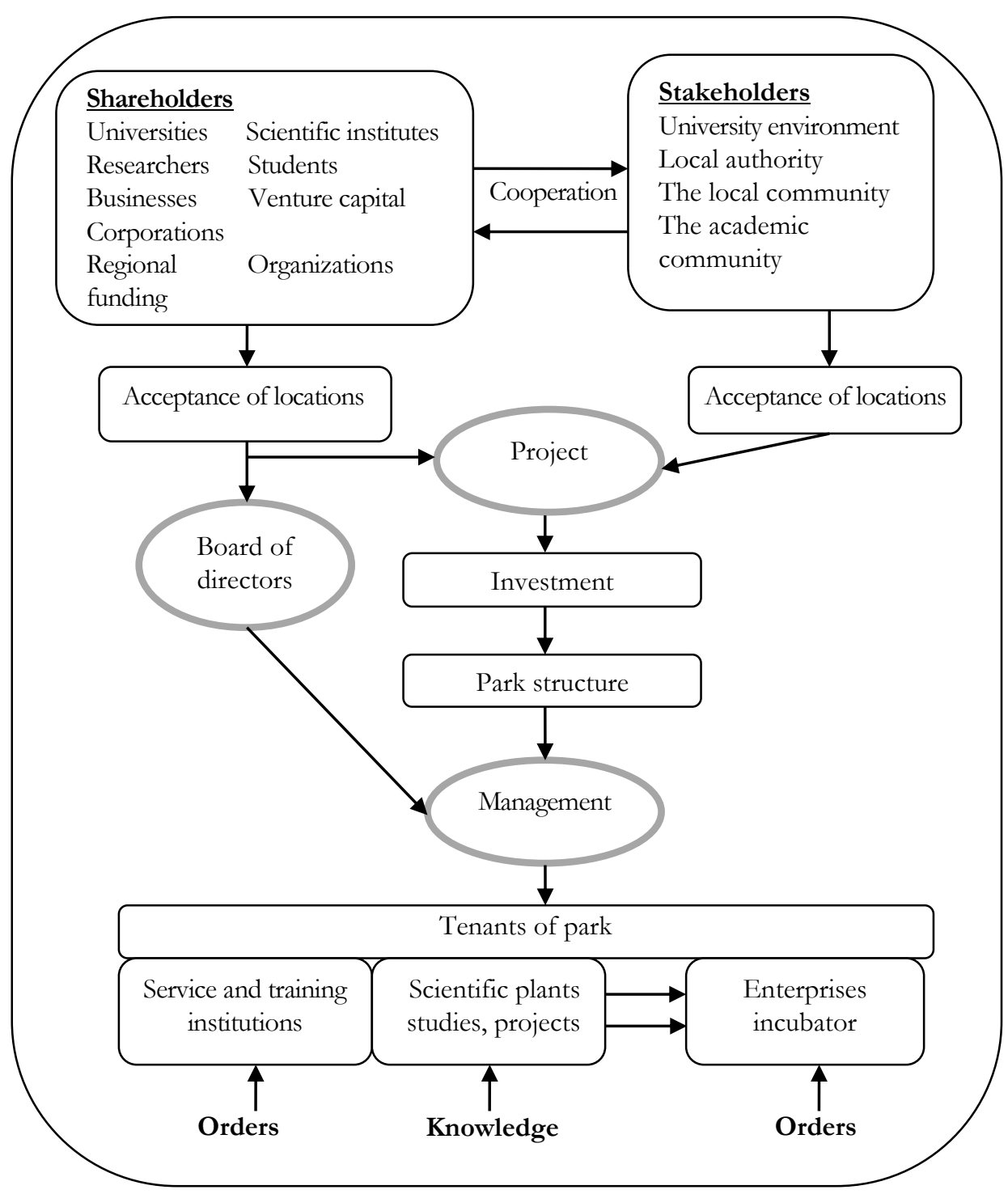

Source: author's own work [Analiza..., 2014, p. 54]

The park manages the board chosen by the founders and a board of directors appointed at the shareholders' meeting. The details of the management system are included in the articles of association adopted by shareholders. From the potential success point of view, an individual leader - chairman of the board, who should be 
an efficient manager with high qualifications combined with working experience in the scientific community, is extremely important.

Potential advantages of the model III

- A park organized according to the proposed rules is a complex structure.

- A potential large shareholder can provide initial capital and inflow of funds for the functioning by selling shares.

- The strength of the park can be power and brand shareholders as for example renowned universities and achievements of scientists working there.

- A park can find appreciation and acceptance of the local environment and local authorities [Analiza..., 2014, p. 55].

Disadvantages of model III

- The size and complexity of the park can be dangerous blurring responsibilities and causing organizational inertia.

- $\quad$ The main problem may be the lack of a potentially large, appropriate to the size of the park number of innovative projects.

- A significant size of the park may make it difficult to operate the infrastructure.

- There may be difficulties in integrating the business scientific community because of a large number of employees [Analiza..., 2014, p. 55].

The corporate model of the park is shown on Chart 3. It presents the process of building the park as independent organization created in close cooperation between groups of shareholders and stakeholders. An important feature of the process of creating the park is that is implemented as an individual project. After creating the park management is executed by the management team subordinate to board of directors.

\section{Model IV - Network park}

The network model assumes that the organization of a science and technology park is formed as a relatively free network system and the management of the park serves as an orchestrator managing and coordinating the activities of independent scientific and business entities cooperating directly or through a network orchestrator. Research institutions or teams of researchers and companies act as nodes of the network. Communication between them is carried out primarily by Internet, it might be online contacts, teleconferencing and other means available by the electronic media. Extensive use of the network allows access to the park not only geographically close, but also remote entities and individuals. Therefore, some entities can be included from other regions in the country, as well as foreign cooperating organizations. In constructing the management model of network, a scientific and technological park needs to specify the basic objectives of the whole organization, functions of the entities participating in the park, the principles of cooperation between the entities, tasks for an orchestrator and its role in relation to the other members of the network. The terms also require the park relationship with the social environment, the authorities and a wider scientific domestic and foreign community. The primary objectives of this kind of a scientific and technology park is to organize cooperation in research and development and the creation of companies implementing innovation projects through the creation of an Internet platform for exchanging information and projects, conducting discussions, conferences in the frame- 
work of park members. Participants of networks are, therefore, a set of knowledge and skills directed for creating products and services complementary to each other and designed to achieve scientific and business objectives multiplying the value created by independent organizations that have declared their affiliation to the park.

The roles of an orchestrator are:

- approving of the function of a park founder,

- developing an organizational concept and statute of the park,

- formulating offers for potential participants,

- opening a cooperation platform

- establishing contacts with potential sources of funding for research and implementation (government and EU funds, venture capital, sponsors, foreign organizations);

- $\quad$ searching for customers projects and partners for business;

- marketing innovation;

- organizing international cooperation.

The Management Board of the park (a network orchestrator) next to financial coordination functions can perform representative functions, but also can administer the material infrastructure of the park also ensuring the exchange of services in this area between the participants of the park. Assuming the organization and economic self-reliance, entities orchestrator's role is to invest in the development of mutual relations and the functioning of information flows on the basis of reciprocity and mutual benefits relative to contributions made. The basis for successful functioning of the network model is the trust of partners, loyalty in the relationship and sharing risk. The proper functioning and management of the network structure of the park also requires the fulfillment of certain technical requirements. Information systems of entities belonging to the park because of the different tasks assigned to them can differ. Networking requires adjustment and compatibility of individual systems. It is a prerequisite that allows seamless flow of information [tobejko, 2012, p. 27].

Chart 4 shows the idea of a science and technology network park management system model. It presents a diagram of network connections in a network park model assuming the central role of the scientific council and the board (management company), as a network orchestrator consisting of both ambient units cooperating with the park, but not belonging directly to the strategic area and entering the corporate network directly associated with the management of the park under concluded agreement on cooperation.

In this model, the park board acts as a coordinator in the terms stipulated in the contracts and while belonging to the park, companies have a legal personality and economic standing as well as they are responsible for the commitments. 
CHART 4.

\section{The management board connections network model}

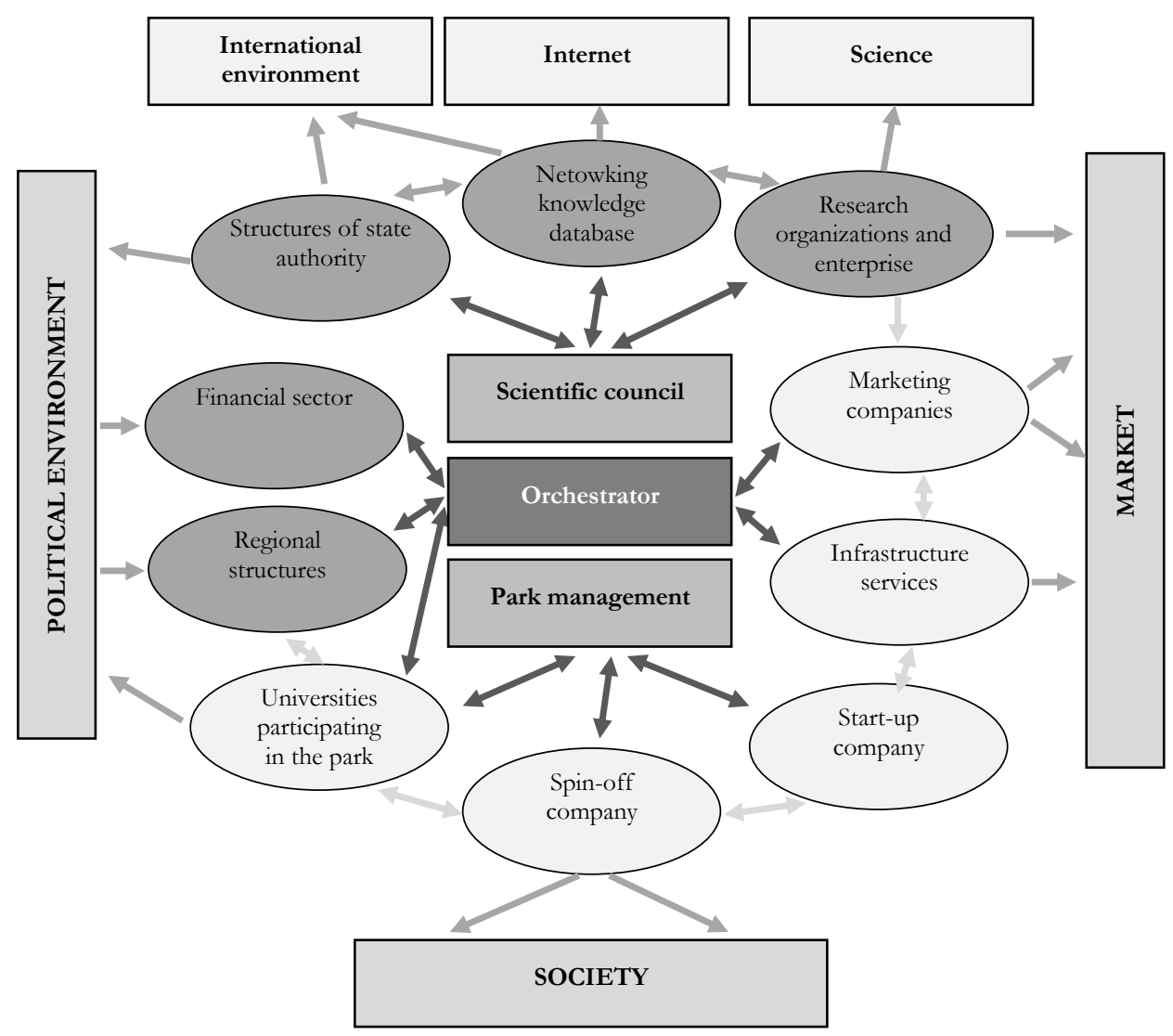

Source: author's own work [Analiza..., 2014, p. 58]

In the chart the strength of relationships has been marked with shades of gray: an orchestrator (dark gray), companies related to contracts (middle gray), and environment organizations (light gray).

Advantages of the network model:

- $\quad$ this model uses measures offered by modern information economy, thus characterized by a high level of modernity;

- $\quad$ participation of entities belonging to the network is voluntary and does not rule out an independent economic activity;

- internal structures and strategy of the network model can be easily adapted to the needs in accordance with the will of participants of the park;

- management system can be based on the principle of consensus and participation in the decision-making process [Analiza..., 2014, pp. 58-59]. 
Disadvantages of the network model:

- complexity of the connections and open access could hamper the formulation of common goals and putting them into effect;

- a complex system can generate costs arising from the incompatibility of information systems;

- division of tasks and responsibilities between park management and leadership of the park participants can be difficult [Analiza..., 2014, p. 59].

\section{Possibilities in network cooperation amongst enterprises}

Enterprises that operate on the basis of cooperation with technology parks, operate in branches of industry with end-products being capital-intensive. All essential investments connected with gaining knowledge and doing research usually exceed enterprises' abilities. Overcoming these barriers may be possible by joining the network with other companies. Cooperation within the network is possible wherever participants share common interests and operate in similar domains despite geographical dispersion. Being a part of a network enables them to achieve the synergy effects that all the parties involved benefit from. Networks mainly give possibility to share knowledge more quickly, new ideas in particular, which is sine qua non of the innovation creation process. What's more, within the network cooperation there are organized lots of events, such as meetings, conferences, access to experts or various databases, where the main role is to lead to information exchange. Additionally, they stimulate the technology transfer and provide easier access to the clients and new funding sources. They also give the possibility to compare themselves to local partners and those operating abroad. Last but not least, networks diffuse and strengthen the use of the so-called good practices, which positively affects the efficiency of work, inside and outside the organization.

Operating within the network is a specific form of interaction between a company and its business environment. It not only ensures the external relations to be coherent and structured, but also enables taking advantage of business solutions as a good source of benefits for a company. Expanding cooperation with entities such as universities, research centres, associations or other enterprises in a harmonious way is also one of the advantages of networks. In a traditional approach to the economy, enterprises treat competitors as rivals that they can only compete with. However, from the network perspective, cooperation between competitors is also possible and yields profits to both sides. As for the market in the context of a network, competition is not a zero-sum game where if one wins the other loses. Companies operating inside the network gain more profit than those performing outside.

In the business environment of companies, apart from the typical professional networks, there are a lot of networks specializing in certain tasks. One can name these specializing in fundraising for its participants. Small enterprises usually encounter problems with financing their development. These constraints mainly stem from the banks being reluctant to finance uncertain projects. From a bank perspective small entities have a weak position on the market and a lack of experience in the finance market 
so their finance offer is usually worse than for big companies. Being a part of a network specialized in fundraising, such as the European Business Angels Network (EBAN) or the European Venture Capital Association (EVCA), gives an opportunity for small and inexperienced enterprises to gain some financial resources for development.

Expansion of relations and the so-called networking are the benefits, among others, that companies can gain through operating in a network. Thanks to that the company and its employees can monitor current changes in a given branch and also gain information about current and planned activity of competitors and cooperating companies.

\section{Conclusions}

The conducted analysis of the selected foreign science and technology parks allowed to formulate four main models of park management. These models in different variations are used in the management of science and technology parks in the world. The study confirms the relatively great diversity of solutions used in practice. However, you can find a clear distinction between applied management solutions into two groups. The first group was formed by models I and II based on close ties with the university, focused on creating of start-ups and academic incubators. The second group of management models are models of type III and IV, used in complex park structures, often without taking up area, which holds up the organization, but forming a network of alliances based on concluded contracts for specific tasks, not only in terms of the commercialization of research, but also covering other areas of business.

Taking into consideration the conditions of the Polish economy and the functioning of $\mathrm{R} \& \mathrm{D}$, the authors believe that the most appropriate for managing a science and technology park are two models: a corporate model and a network model. As Polish and foreign experience has shown only strong and of high standing scientific research technical universities are able to independently undertake a park development initiative. In the case of Polish technical universities in the implementation of park initiatives, it is necessary - according to the corporate model - that there was inclusion of both public shareholders and private, who are interested in the potential possibility of a return of capital in the long term. Forming the corporate park management is also beneficial for the university located in the park because they do not have to become directly involved in park management that performs on their behalf designated for this purpose corporation management.

The financial support of public and private shareholders for the development of the park is also significant. A network model is the second worth a recommendation for Poland model for managing a science and technology park, in which the board of the park plays the role of an orchestrator managing and coordinating the activities of independent scientific and business entities. In this model, a science and technology park form teams of researchers and companies joined and working together in an interactive manner based on computer networks. Thanks to this, cooperation is possible not only with entities close geographically but also those from other regions, including foreign ones. Past experience in the development of science and technology parks 
indicate that the network model park in the future will play an important role in the development of R \& D and the commercialization of research results.

\section{References}

Analiza najlepsyych praktyk dla modutu zarzadzania parkiem technologicznym i biznesonym, 2014, Raport z badania międzynarodowych parków naukowo-technologicznych zrealizowany na zlecenie firmy Pro-Development, Warszawa.

Florida R. 2010 Narodziny klasy kereatymnej, Narodowe Centrum Kultury, Warszawa.

Gorynia M., Jamkowska B. 2007 Koncepcje klasterów jako sposób regulacji zachowań podmiotón gospodarcsych, „Ekonomista”, nr 3.

International Association of Science Parks Survey 2014, http:/ /www.iasp.ws/statistics, retrieved: 12.11.2014.

Lobejko S. 2010 Pržedsiebiorstwo sieciowe. Zmiany unarunkowan i strategii w XXI wieku, Szkoła Główna Handlowa w Warszawie, Warszawa.

Marciniec B. M. 2007 Rola parków naukowo-technicznych w rožwoju matych i średnich pržedsiebiorstw, Wydawnictwo Poznańskie, Poznań 2007.

Strategiczne obszary rozwoju parków technologicznych, 2011, K. B. Matusiak (ed.), PARP, Warszawa.

Nauka - Edukacja - Technologia (NET) Parki Technologiczne USA, Management and Organization of Technology Parks in the US Raleigh/Newark/Philadelphia/College Park/Rockville 18-25 kwietnia 2007, http://deltechpark.org/, retrieved: 25.11.2014.

Opinia Europejskiego Komitetu Ekonomiczno-Spotecznego w sprawie „Europejskie parki technologiczne, przemystowe i naukowe w dobie zarzadzania krysysem, praygotowania do okresu po krysysie $i$ strategia po cyklu lizbońskim" (additional opinion), 2011/C 44/22, Bruksela, 14 lipca 2010.

Przeedsiębiorstwa siecione i inne formy wspótpracy sieciowej, 2012, S. Lobejko (ed.), Oficyna Wydawnicza SGH, Warszawa.

Raport Parki przemystowe, technologiczne i specjalne strefy ekonomiczne, 2009, IPO, http://www.ipo.pl/raporty/parki_przemyslowe_2009.pdf, retrieved: 5.11.2014.

Sanni M., Egbetokun A., Syianbola W. 2009 A Model for the Design and Development of a Science and Technology Park in Developing Countries, National Centre for Technology Management, Inderscience Publishers, online at http://mpra.ub.uni-muenchen.de/ 25342/MPRA Paper No. 25342, posted 28. September 2010, retrieved: 10.11.2014.

Science Parks around World, http://www.unesco.org/new/en/natural-sciences/sciencetechnology/university-industry-partnerships/science-parks-around-the-world, retrieved: 15.11 .2014$.

Setting up, Managing and Evaluating EU Science and Technology Parks. An Advice and Guidance Report on Good Practice, 2014, "Regional and Urban Policy", EU 2014.

The World Bank Report "Plan and Manage a Science Park in the Mediterranean", http://www.eib.org/attachments/country/plan-and-manage-a-science-park-inthe-mediterranean_en.pdf, retrieved 12.11.2014.

Weresa M. A. 2014 Polityka innowacyjna, Wydawnictwo Naukowe PWN, Warszawa 2014. 